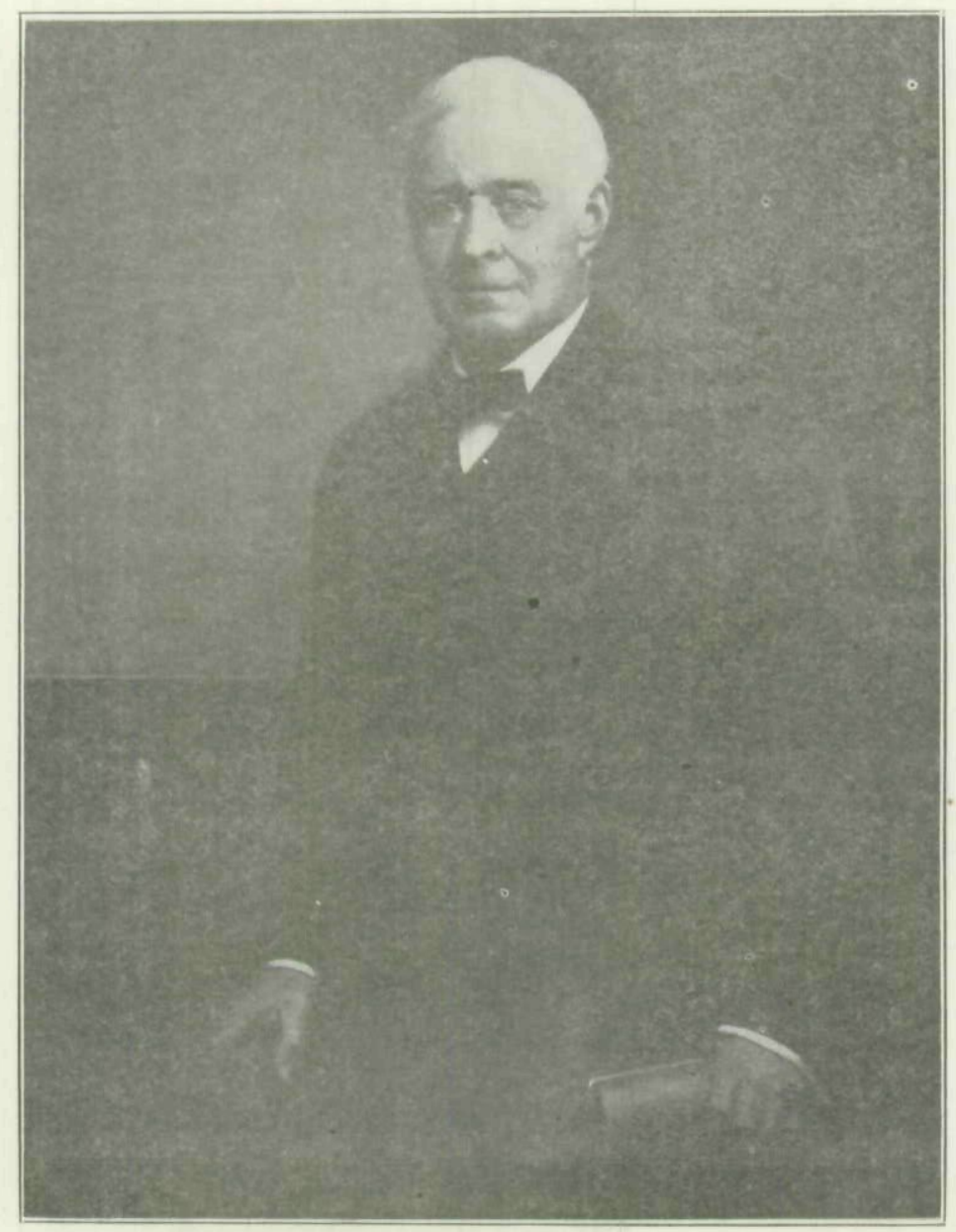

HORACE BOIES

From a painting in oil by George $H$. Yewell, in the collections of the Historical, Memorial and Art Department of Iowa. 


\section{AN AUTOBIOGRAPHICAL SKETCH OF GOVEERNOR BOIES}

Albert J. Edwards of Waterloo, of the firm of Edwards, Longley, Ransier \& Harris, lawyers, has recently turned over to the Historical Department his original correspondence in which the late Governor Boies set out in autobiographical form the salient features of his life and public career. In order that this correspondence may be made available to the public, and especially to students, we reproduce it in full.

Mr. Edwards says, "I had a very high personal regard for Governor Boies. It was while I was deputy clerk of our court that he was in the office one day and said to me, 'Albert, you ought to read law while you are here. You are getting the practice and a wide acquaintance, and if you should ever want to practice law you would be fitted for it.' At that time Mr. Boies was the leading lawyer in this part of the state and naturally I followed his suggestion, and was admitted in 1880 . In $1880 \mathrm{I}$ was elected clerk of the district court, which office I held for six successive terms. Mr. Boies's suggestion followed by me undoubtedly changed the whole tenor of my life. I have been in the active practice of the law since January 1, 1898, and now at the age of nearly seventy-eight I am still engaged therein."-EDịor.

Law Offices of

\section{EDWARDS \& LONGLEY}

Commercial Bank Bldg.

Waterloo, Iowa

Albert J. Edwards

Alfred Longley

Nov, 22, 1905 .

Hon. Horace Boies,

Grundy Center, Iowa.

Dear Governor:

I have been requested to prepare a history of the Black Hawk County bar, and would esteem it a great favor if you would send the data in regard to your personal history in connection with the bar, together with the dates that you were governor of this state, and such other information as will enable me to give a correct history.

Yours very truly,

Dic. A. J. E.

A. J. EDWARDs. 
A. J. Edwards, Esq.,

Grundy Center, Nov. 25, 1905.

Waterloo, Iowa.

Dear Sir:

Yours of the $22 \mathrm{~d}$ inst. is received. My connection with the Black Hawk County bar began in the month of April, 1867, and continued until the first of January, 1890.

Before coming to Waterloo I had arranged with $\mathrm{H}$. B. Allen to join him in the practice of our profession at that place and immediately upon my arrival entered his office and our business was conducted under the firm name of Boies \& Allen.

The late Judge Couch was as I remember a student in Mr. Allen's office when I came to Waterloo and remained in the office until he was admitted to practice, after which (but at what precise date I do not now remember) he was taken into [the] firm and the business was conducted under the firm name of Boies, Allen \& Couch. This firm continued in practice until the late seventies (but the exact year I do not now remember) when Mr. Allen on account of poor health retired from the firm.

About this time my oldest son, E. L. Boies, was admitted to practice and he was taken into the firm and the business was conducted under the firm name of Boies, Couch \& Boies. This firm continued until the election of Judge Couch as district judge, but I am not now able to state definitely the year that this occurred. Soon after the retirement of Judge Couch from the firm Judge Husted was taken into the firm and the business was conducted in the firm name of Boies, Husted \& Boies. This firm continued until I was elected governor and was inaugurated about the middle of February, 1890, instead of January, because of a deadlock in the legislature. I held that office until January $1,1904$.

I hope you will not deem it egotistical in me to say that while I was connected with the several firms aforesaid, the business of the several firms was so extended that we were employed in many important jury trials in a dozen or more different counties in this section of the state.

Respectfully yours,

H. BoIEs.

Law Offices of

EDWARDS \& LONGLEY

Commercial Bank Bldg.

Waterloo, Iowa

Alfred Longley

Dec. 2, 1905.

Hon. Horace Boies,

Grundy Center, Iowa.

Dear Governor:

I received your letter of the 25th ult., and thank you for the informa- 
tion contained. But it has occurred to me that, on account of the distinction which you obtained in your profession and the fact that you were governor of this state, it would be well to have something of a history of your early life and legal education, where you were admitted to the bar, etc. I have understood, I do not know whether from you or others, that your early education was limited, and that you have won distinction in your profession and in the state by overcoming the disadvantages of your early life. It seems to me that a record of this might be an incentive to those who will read the history of the Black Hawk County bar.

I do not want to trouble you in this matter, but as you won greater distinction than any other member of the Black Hawk County bar, and acquired not only a state but a national reputation, $I$ believe that what I have suggested will be of interest to all who will read the history.

Yours very truly,

Dic. A. J. E.

A. J. Edwands.

\section{A. J. Edwards, Esq., Waterloo, Iowa. \\ Dear Sir:}

Yours of the 2nd inst. reached me last evening. The only hesitation I feel in giving you the information you request is the fear that I may be thought egotistical in furnishing it. I have, however, overcome my first impressions on that point and concluded to supply you with a simple statement of facts, trusting to your judgment to [so] use them that they will not seem to have been supplied by me for the purpose of self-glorification.

My first recollection of life was a home in a log house with my parents and older children in a new and sparsely settled section of Erie County, New York, some twenty miles distant from the city of Buffalo. This place continued my home constantly until I reached the age of sixteen years, and by the time I was old enough to be of assistance on my father's farm I was constantly engaged with him in the summer season in chopping down the forest trees, clearing up the land, and cultivating that part of the farm that had heen prepared for crops.

In the years of my life before I was old enough to be of assistance on the farm my school advantages were extremely limited. My first recollection of school was one taught by a lady in an abandoned blacksmith shop a couple of miles or more from my father's house. For many years after this I was compelled to travel a long distance to reach a school of any kind, and when able to do this it was only for a brief period in summer that such a school was in session. About the time I reached the age of ten or twelve years a school district was organized that included my father's farm and a little school house built near our 
home and from that time until I left home, some four or five years later, I had and improved the opportunity of attending a winter school three months each year. This comprised my school advantages prior to the [age] of seventeen years.

The spring after I was sixteen, after long pleading, I induced my father and mother to consent to my leaving home and going to what was then the territory of Wisconsin. After a journey of seven days around the lakes on a propellor I landed at Racine, Wisconsin, with seventyfive cents in my pocket and all of my earthly belongings tied up in a red bandana handkerchief. I soon found employment on a farm and from that time until I reached my majority nearly all of my time in summer was spent in the West, principally in northern Illinois. In winter I usually went back to New York and attended the district school in my father's district three months each winter, with a variation from this of one term of three months in a select private school, and one winter term at Beloit, Wisconsin, in the first days of that school. This comprised my school advantages.

At the age of twenty-one years through the influence of the girl that became my wife I was induced to enter a law office as a student and try to prepare myself for the practice of that profession. I was fortunate enough to find a country practitioner in one of the little villages of Erie County, New York, who took me into his family and allowed me to do chores for my board.

I stayed in his office two years, with the exception of a vacation each year of a month or six weeks which I used to work in the hay and harvest fields to earn a little money to replenish my meager finances, and at the end of this two years at a general term of the Supreme Court of the judicial district in which I read law, I applied for admission to the bar. There were twelve other applicants, so the court had a class of thirteen. Among them were students who had been in a law office five years, none I think who had spent less than three except myself, and few who had spent less than four. Our examination was a severe one lasting through three separate sessions of the court, and conducted by examiners appointed by the court in the presence of the four judges of which the court was composed. Of this class four only of the thirteen applicants were admitted, of which number I was fortunate enough to be one. Nine of the applicants were rejected.

About the time I was admitted to practice the man with whom I read law removed from the little village where I read and I took his office with a secondhand "Digest of New York Reports," a copy of "Kent's Commentaries," and a copy of "Cowen's Treatise" (a work on justice court practice) for my library. After a stay of a year or thereabouts in this place, I removed to what is now the town of Hamburg, some ten or twelve miles from Buffalo, where I remained in practice until I came west. During these years I had built quite a practice for a country lawyer, but had never forgotten my admiration of the West and gladly availed myself of the first opportunity I had to settle here. 
Possibly I ought in this connection to say something of my political experience. While in practice at Hamburg I was surprised one day by the return of delegates from an assembly district convention, who told me I had been nominated by the Republican convention of the district for the New York Assembly from that district. It was the first information I had that anyone thought of me in connection with that office. I was elected and served one term. Before the next meeting of the legislature my assembly district was changed so as to give the Democrats the controlling vote in the district and I was defeated at the next election.

This ended my political experience until I was even more surprised while on a return trip from the Pacific Coast to read one day in a morning paper that I had been nominated for governor by the Democrats of Iowa. Each of these nominations came to me wholly unsolicited, and so far [as] the nomination for governor of Iowa was concerned I would gladly have declined it had I felt that it was a moral right of any citizen to decline such an honor that came to him unsolicited. I had, however, no expectation of being elected and was as much surprised by the result as any one in the state. I was glad to receive the approval of my party manifested in a unanimous nomination for a second term, and still more grateful that the people of Iowa were willing to honor me with a second term of that office.

My third nomination was against my own wishes expressed in emphatic terms not only to separate leaders of my party in the state, but published in leading papers of my party throughout the state. When the convention met, however, there were two delegates and two only in that body who openly questioned the propriety of nominating [me] for a third term. With the exception of these two men it appeared to me there was a unanimous demand of the other members of the convention that I should accept the nomination and I felt (whether wisely or not others must judge) that I could not rightfully decline it.

Certain it is that I have always felt that with my second election to the exalted office of governor of my state the people of Iowa had bestowed upon me immeasurably greater honor than I deserved or had any right to expect, and with my election to that office for a second term I was anxious to call my political career in the polities of my own state at least forever closed.

My nomination for Congress in the Third District was not only wholly unsolicited, but it would not have been accepted by me had I not felt that it was necessary to shield my son from criticism because his condition of health, then unknown to the general public, absolutely forbade his acceptance of that nomination.

It is perhaps not improper for me in this connection to mention one other incident in my political experience. President Cleveland, when forming his cabinet for his second term of office, offered me the position of secretary of agriculture in that cabinet. This I declined for the 
double reason that its acceptance would compel my resignation as governor of the state and for the further and more controlling reason that I did not believe myself qualified to discharge the duties of that office.

Now, Mr. Edwards, let me say I have written all this very hurriedly. It seems to me the great bulk of it would [be] more appropriate in an obituary notice than it would be in the history of Black Hawk County bar, but having little time to discriminate between what is and what is not fit for use in such a history, I have laid my life bare before you that you may use what you want for your purpose and discard the rest. Sincerely yours,

H. BorEs.

\section{FESTIVAL AT MOUNT PLEASANT}

Owing to the severity of the weather and a press of work, we were not permitted to be present at the Mount Pleasant Plank Road celebration, but we learn from the reports that it passed off quite agreeably and in a manner altogether satisfactory to those who did attend. A very large delegation attended from Burlington and we regret that the weather and the roads did not permit Fairfield to be more numerously represented. Good roads are undoubtedly a great convenience and we congratulate our Mount Pleasant friends on their good fortune in having so convenient an outlet to the river. We hope at an early day to celebrate the completion of the Fairfield and Mount Pleasant Plank Road, and then won't we have a great time! Hurrah for plank roads! They are the very thing.-The Fairfield Ledger, December 24, 1851. (In the newspaper collection of the Historical, Memorial and Art Department of Iowa.) 
Copyright of Annals of Iowa is the property of State of Iowa, by \& through the State Historical Society of Iowa and its content may not be copied or emailed to multiple sites or posted to a listserv without the copyright holder's express written permission. However, users may print, download, or email articles for individual use. 